\title{
RANCANG BANGUN SOLAR WATER HEATER DENGAN KOLEKTOR PELAT DATAR BERBENTUK SPIRAL BERBASIS MIKROKONTROLER
}

\author{
Ocsirendi ${ }^{1}$, Indra Dwisaputra ${ }^{2}$, M. Yusuf ${ }^{3}$, Irfan Rahmi ${ }^{4}$ \\ 1,2,3,4 Jurusan Teknik Elektro dan Informatika, Polekteknik Manufaktur Negeri Bangka Belitung \\ Kawasan Industri Air Kantung, Sungaliat-Bangka, 33211 \\ Tel: 0717-93586, Fax: 0717-93585
}

\begin{abstract}
Bangka Island has high sunlight intensity, but it still has little use as an alternative energy source. Water heater available on the market have experienced a peak of innovation that continues to use electricity as energy, but as we know that heater that use electricity consume a lot of energy. In this research, a solar water heater machine with spiral collector will be made to heat water in a reservoir using sunlight energy and as a tool to see the difference between the continuous method which circulates water continuously from the reservoir to the heat collector with a delay method that circulates water with a certain delay time. Both methods and data retrieval mechanisms are controlled by an Arduino device. Based on the results of the trial, it was found that Solar water heater was able to heat water in reservoir up to 48.92 degrees Celsius and the use of the continuous method made the water temperature higher than the delay method with a maximum difference of 10.66 degrees centigrade.
\end{abstract}

Keywords :Circulation, Flat Plate Collector, Solar Water Heater

Abstrak

Pulau Bangka memiliki intensitas cahaya matahari yang tinggi, namun masih sedikit pemanfaatannya sebagai sumber energi alternatif.Pemanas air yang tersedia di pasar hingga saat ini mengalami puncak inovasi yang tetap memanfaatkan listrik sebagai energi, namun seperti yang kita ketahui bahwa pemanas yang menggunakan energi listrik mengkonsumsi daya yang tidak sedikit. Pada penelitian ini akan dibuat sebuah alatSolar Water Heater yang menggunakan kolektor berbentuk spiral untuk memanaskan air didalam tandon air yang memanfaatkan energi sinar matahari serta sebagai alat untuk melihat perbedaan antara metode continue yang mensirkulasi air secara terus menerus dari tandon air ke kolektor pemanasdengan metode delay yang mensirkulasi air dengan jeda waktu tertentu. Kedua metode serta mekanisme pengambilan data dikendalikan oleh sebuah perangkat Arduino.Berdasarkan hasil ujicoba, didapatkan bahwa Solar Water Heatermampu memanaskan air pada tandon air hingga 48,92 derajat celcius serta penggunaan metode continue membuat suhu air lebih tinggi dari metode delay dengan perbedaan maksimal sebesar 10,66 derajat celcius.

Kata kunci :Sirkulasi, Kolektor plat, Solar Water Heater

\section{PENDAHULUAN}

Matahari merupakan bagian dari sistem tata surya berupa bintang besar yang mampu menghasilkan panas dan cahayanya sendiri, dan dikelilingi planet-planet lain salah satunya Bumi. Cahaya matahari pun merupakan sumber energi terpenting bagi manusia dan tumbuhun yang ada di alam semesta. Salah satu contohnya selain cahaya matahari dapat diubah menjadi energi listrik, cahaya matahari juga dapat dimanfaatkan sebagai pemanas air alami. Akan tetapi pemanas air alami yang menggunakan cahaya matahari yang ada dipasaran, kendala utamanya adalah biaya yang cukup mahal. Sebagai contoh pemanas air berkapasitas 280 liter berharga berkisar Rp 12.000.000, untuk tipe yang menggunakan penutup kaca biasa dan Rp 15.000.000, untuk tipe yang menggunakan penutup kaca jenis temper light [1]. Pemanas air yang tersedia di pasar pun hingga saat ini mengalami puncak inovasi yang tetap memanfaatkan listrik sebagai energi. Maka dari itu, perlu sebuah inovasi yang dapat meminimalisir persoalan tersebut [2]. Solar water Heater (SWH), merupakan suatu alat yang memanfaatkan panas dari sinar matahari untuk menaikkan suhu air, dengan menggunakan penggumpul-pengumpul panas yang di sebut kolektor plat [3]. Rancang bangun ini lebih difokuskan pada efisiensi dan optimalisasi biaya. Rancang bangun ini menggunakan sistem pasif. Disebut menggunakan sistem pasif karena rancang bangun alat ini 
hanya mengandalkan radiasi panas matahari sepenuhnya. Adapun pengumpul panas dari cahaya matahari adalah sebuah pipa tembaga atau kolektor penyerap panas radiasi matahari yang diletakkan diatas pelat datar, sehingga dapat mengkonsentrasikan panas pada air yang ada dalam kolektor tersebut [4].

\section{METODE PENELITIAN}

Pada penelitian ini, dilakukan beberapa tahapan sebagaimana yang dapat dilihat padaflowchartpada Gambar 1.

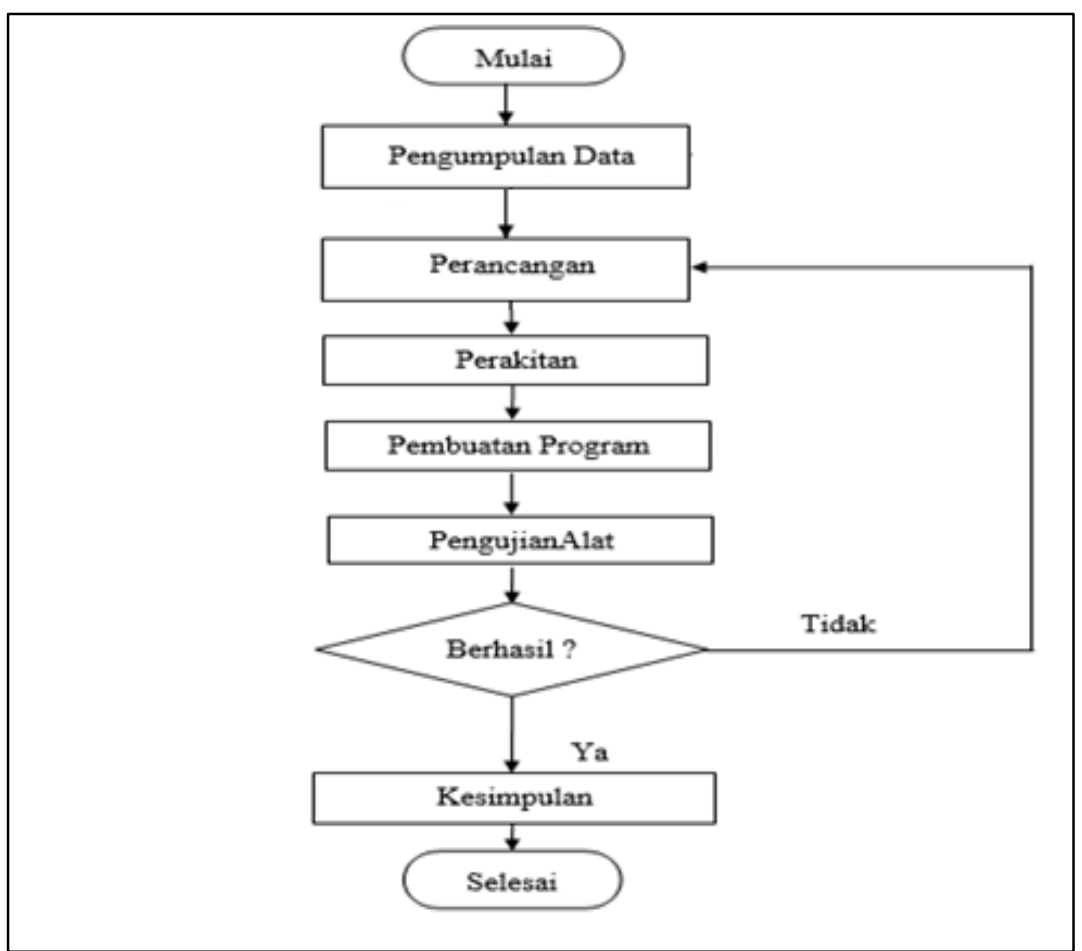

Gambar 1 Flowchart Pelaksanaan

\subsection{Pengumpulan data}

Pengumpulan data dilakukan dengan beberapa metode yang bertujuan untuk mendapatkan data-data yang mendukung yaitu dengan observasi, wawancara, serta studi pustaka. Dalam proses ini bertujuan untuk mengetahui permasalahan-permasalahan yang berhubungan dengan sistem pemanas dari tenaga matahari. Permasalahan yang ditemukan dari observasi tersebut diantaranya pengaplikasiannya ke kondisi nyata dan kolektor panas membutuhkan perancangan desain alat yang tepat agar sensor dapat mengambil data suhu air yang berada didalam pipa tembaga dengan baik.

\subsection{Perancangan}

Pada tahap ini dirancang konsep dan desain yang akan diterapkan untuk memanaskan air dengan cahaya dari panas matahari. Untuk memudahkan penganalisaan,maka desain mesin dibagi menjadi beberapa bagian yang merupakan bagian dari kesatuan rangkaian sistem yang akan dirancang.

\subsection{Pembuatan}

Pada tahapan pembuatan komponen elektronika, komponen elektronika digunakan dan diprogram untuk melakukan monitoring suhu kolektor pipa di atas meja dan suhu air yang berada di dalam tangki yang dipanaskan oleh matahari. Pada sisi konstruksi, Solar Water Heater dibuat menggunakan kayu, triplek, dan pelat seng. 


\subsection{Perakitan}

Pada tahap ini proses dilakukan proses menggabungkan Sparepart menjadi suatu alat yang sesuai dengan perancangan sehingga hasil yang diinginkan bisa tercapai. Proses perakitan menggunakan prosesproses permesinan, dimulai dengan proses pemasangan kolektor panas, peletakan tangki air dan pangaplikasian Box mikrokontroler, serta penyusunan kabel-kabel dan peletakan komponen elektronika yang digunakan.

\subsection{Pembuatan Program}

Pada tahap ini, kegiatan yang dilakukan diantaranya adalah merancang program monitoring suhu air yang dipanaskan oleh matahari dengan perantara pipa tembaga, kemudian Liquid Crystal Display (LCD) digunakan untuk menampilkan suhu dari air dan sinar matahari yang menggunakan sensor suhuDS18B20, dan juga menampilkan volume tangki serta waktu dengan modul Real Time Clock(RTC).Data disimpan ke modul SD Card melalui arduino.

\subsection{Pengujian}

Pada tahapan pengujian alat, kegiatan yang dilakukan diantaranya adalah pengujian pembacaan nilai suhu yang dihasilkan dari sinar matahari serta suhu air dari proses pemanasan.

\section{HASIL DAN PEMBAHASAN}

\subsection{Rancangan Solar Water Heater}

Solar Water Heater dirancang dan dibuat dengan bahan material yang digunakan adalah kayu dengan ketebalan $5 \mathrm{~cm}$. Berikut ini adalah Solar Water Heater(SWH)yang telah selesai dibuat tampak atas dan SWH tampak samping sebagaimana yang ditunjukkan pada Gambar 2.

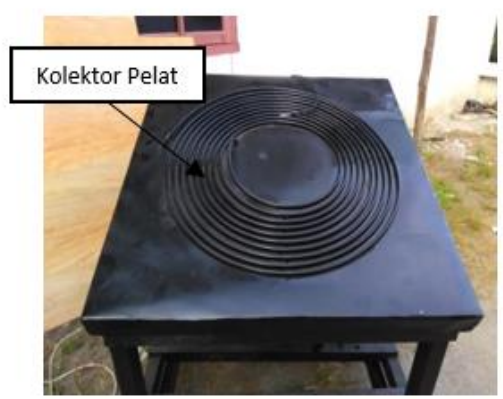

(a)

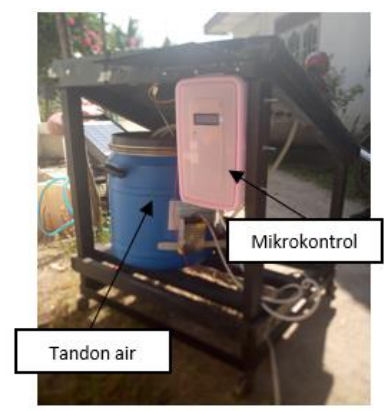

(b)

Gambar 2 (a) SWH Tampak atas (b) SWH tampak samping

Pada proses perencanaannya perancangan konstruksi yang dibuat ada 5 section yaitu proses perencanaan desain konstruksi Solar Water Heater, proses pembuatan kerangka Solar Water Heater dengan ukuran $80 \mathrm{~cm} \times 80 \mathrm{~cm}$, proses pembuatan meja atau dudukan kolektor plat, proses pelapisan plat seng pada meja dan proses pemasangan kolektor plat diatasmeja yang telah dilapisi oleh plat seng.

Hubungan antara komponen elektronika satu dengan yang lainnya ditunjukkan melalui diagram blok pada Gambar 3.

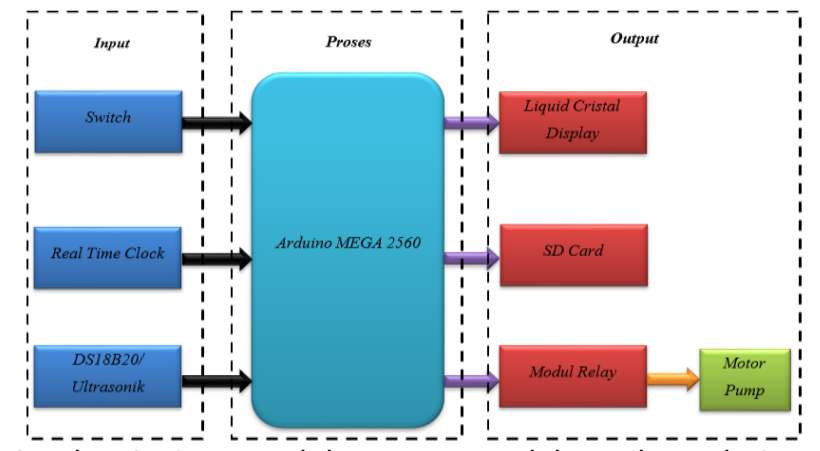

Gambar 3 Diagram Blok Komponen Elektronika pada SWH 
Pengujian Solar Water Heater (SWH) yang dilakukan meliputi pengujian terhadap suhu kolektor plat dan suhu air pada tandon, dimana akan dilihat perbandingan antara metode continue dan metode delay. Metode continue itu sendiri adalah air dipompa secara terus menerus dan sirkular melewati kolektor plat. Sedangkan metode delay adalah air dipompa dalam waktu 20 detik untuk mengisi kolektor plat dan kemudian dipanaskan selama 5 menit, setelah dipanaskan air masuk kembali ke tendon air. Pada metode delay, proses yang sama berlangsung secara terus menerus.

\subsection{Data Hasil Pengujian Sistem Continue dan Sistem delay}

Berikut ini adalah data suhu dari kolektor plat dan suhu dari tandon air dengan metode continue dan delay. Data yang diambil dilakukan selama 3 hari secara bersamaan, dimana cuaca pada hari pengambilan data tidak konstan atau kondisi cahaya matahari berubah-ubah. Penyimpanan data dilakukan menggunakan data logger. Adapun data pengujian suhu pada kolektor plat dan tandon air sebagaimana yang ditunjukkan pada Tabel 1.

Tabel 1 Data Pengujian Suhu Pada Kolektor Plat Dan Tandon

\begin{tabular}{|c|c|c|c|c|c|c|c|c|c|c|c|c|}
\hline \multirow[t]{4}{*}{ Waktu } & \multicolumn{6}{|c|}{ Suhu Dari Kolektor Pelat (derajat celcius) } & \multicolumn{6}{|c|}{ Suhu Air Pada Tandon (derajat celcius) } \\
\hline & \multicolumn{3}{|c|}{ Sistem Continue } & \multicolumn{3}{|c|}{ Sistem Delay } & \multicolumn{3}{|c|}{ Sistem Continue } & \multicolumn{3}{|c|}{ Sistem Delay } \\
\hline & \multicolumn{3}{|c|}{ Hari ke- } & \multicolumn{3}{|c|}{ Hari ke- } & \multicolumn{3}{|c|}{ Hari ke- } & \multicolumn{3}{|c|}{ Hari ke- } \\
\hline & 1 & 2 & 3 & 1 & 2 & 3 & 1 & 2 & 3 & 1 & 2 & 3 \\
\hline 10:00-11:00 & 61.81 & 60.76 & 63.53 & 50.42 & 54.66 & 46.84 & 36.17 & 36.17 & 36.14 & 30.25 & 32.71 & 28.97 \\
\hline 11:00-12:00 & 60.56 & 65.13 & 62.46 & 48.45 & 57.83 & 55.84 & 39.61 & 40.23 & 35.25 & 30.17 & 35.89 & 34.21 \\
\hline $12: 00-13: 00$ & 55.84 & 58.43 & 55.51 & 49.13 & 60.43 & 42 & 42.66 & 42.66 & 34.19 & 32.14 & 38.97 & 30.68 \\
\hline $13: 00-14: 00$ & 58.82 & 68.14 & 54.57 & 51.08 & 59.6 & 43.35 & 43.48 & 44.48 & 37.73 & 35.71 & 39.83 & 30.88 \\
\hline $14: 00-15: 00$ & 63.86 & 70.41 & 57.06 & 39.7 & 49.81 & 41.32 & 46.37 & 47.37 & 41.16 & 37.12 & 42.12 & 30.45 \\
\hline $15: 00-16: 00$ & 58.54 & 61.54 & 48.9 & 37.37 & 49.36 & 39.40 & 46.99 & 48.92 & 42.78 & 36.3 & 41.87 & 39.25 \\
\hline $16: 00-17: 00$ & 44.06 & 43.06 & 38.79 & 33.14 & 41.81 & 38.32 & 45.78 & 45.78 & 42.04 & 35.3 & 41.61 & 38.42 \\
\hline $17: 00-18: 00$ & 32.82 & 32.12 & 31.2 & 29.96 & 50.73 & 36.42 & 40 & 42.12 & 39.36 & 34.07 & 39.55 & 38.31 \\
\hline
\end{tabular}

Keterangan:

$\begin{array}{ll}\text { Hari } 1 & =1 \text { Agustus } 2018 \\ \text { Hari } 2 & =3 \text { Agustus } 2018 \\ \text { Hari } 3 & =4 \text { Agustus } 2018\end{array}$

Berikut ini merupakan grafik perbandingan nilai suhu air pada tandon di hari ke-1 seperti yang ditunjukkan pada Gambar 4.

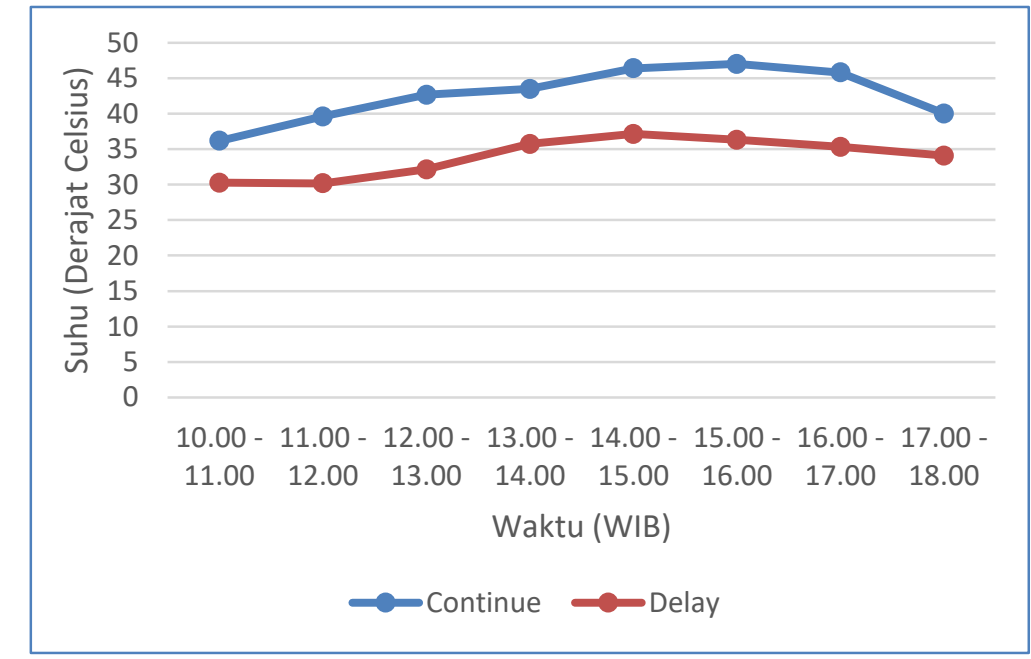

Gambar 4 Grafik Perbandingan Nilai Suhu Air Pada Tandon Di Hari Ke-1

Berikut ini merupakan grafik perbandingan nilai suhu air pada tandon di hari ke-2 dan ke-3 seperti yang ditunjukkan pada Gambar 5 dan Gambar 6. 


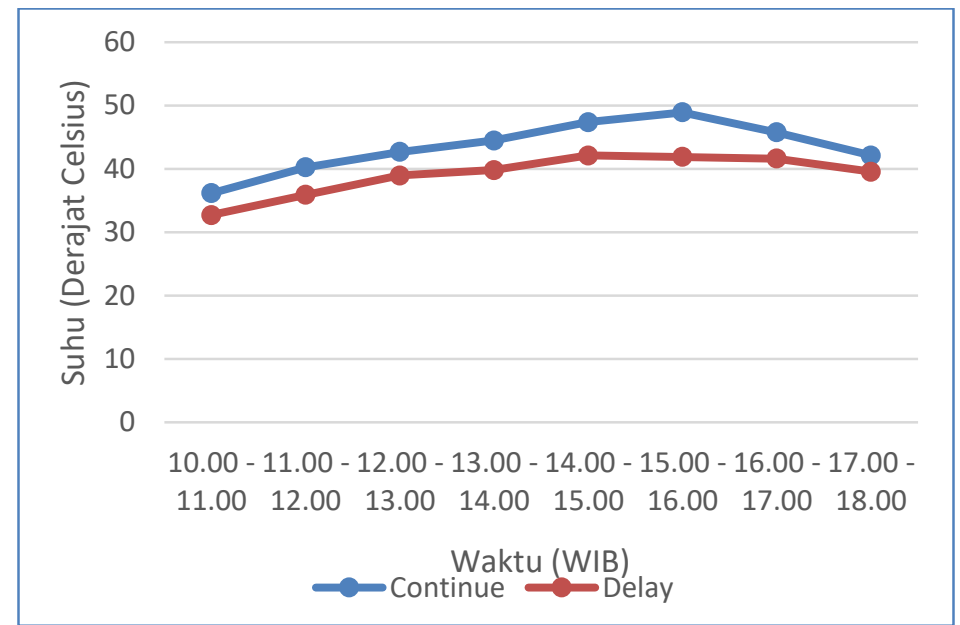

Gambar 5 Grafik Perbandingan Nilai Suhu Air Pada Tandon Di Hari Ke-2

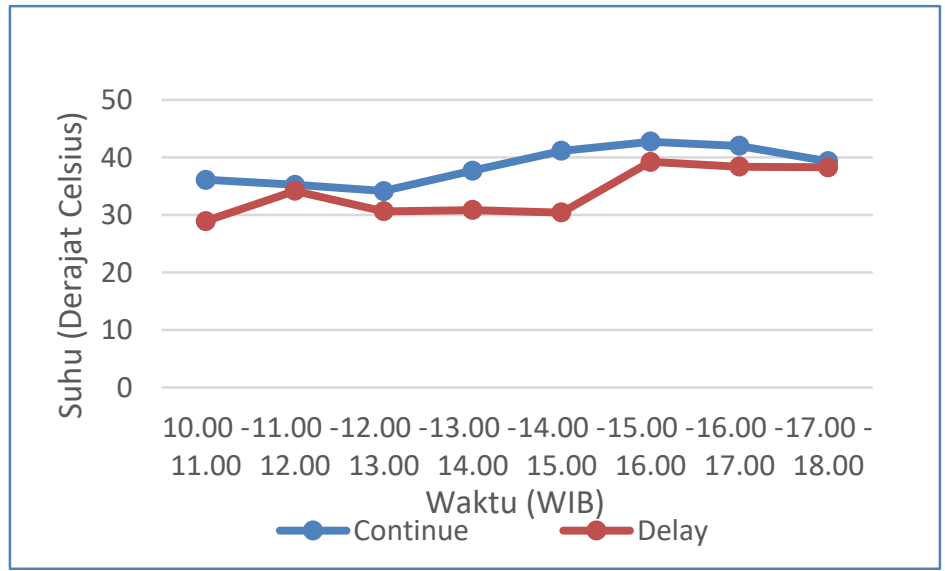

Gambar 6 Grafik Perbandingan Nilai Suhu Air Pada Tandon Di Hari Ke-3

\section{SIMPULAN}

Bedasarkan hasil pengujian dan analisa dapat ditarik kesimpulan sebagai berikut :

1. Solar Water Heater mampu memanaskan air pada tandon air dengan suhu maksimal 48,92 derajat celcius.

2. Secara umum, suhu maksimal pada kolektor plat menggunakan kedua metode terjadi pada kisaran pukul 14.00 - 15.00 WIB. Sedangkan air pada tandon air memiliki suhu tertinggi pada kisaran pukul 15.00 - 16.00 WIB untuk metode continue, dan pukul 14.00 - 15.00 WIB untuk metode delay.

3. Berdasarkan hasil pengujian, dapat dilihat bahwa metode continue lebih baik dibandingkan dengan metode delay dalam hal efektifitas pemanasan air dengan perbedaan maksimal mencapai 10,66 derajat celcius, namun konsumsi daya listrik oleh pompa akan semakin besar karena pompa menyala secara terus menerus.

\section{DAFTAR PUSTAKA}

[1]. Rizki Ikhsan, dkk, "Studi Kinerja Solar Water Heater Double Plate dengan Aliran Zig-Zag Berbalur Balok", Jurnal Rekayasa Mesin, Vol 8, pp 37-36, 2017.

[2]. Nizar Ramadhan, dkk, "Analisa Perbandingan Panas Pada Kolektor Pemanas Air Tenaga Surya dengan Turbelance Encher", Jurnal Rekayasa Mesin, Pp 15-22, 2017.

[3]. Calaeiss Matthieu, "Using Arduino to Monitor an Homemade Energy Autonomous Platform", TEKTOS IUT de Saint-Omer Dunkerque - Dept. Gẽnielndustriel et Maintenance- Longuenesse, FR62698, 2014.

[4]. Shelmi, M, dkk, "Validation of CFD simulation for flat plate solar energy collector", Renewable Energy, Vol 8, pp. 383-387, 2008. 